\title{
COURRIER
}

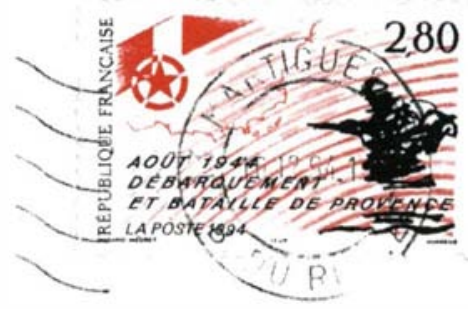

\section{Plainte pour assistance à personne en danger}

Une femme a une leucémie aiguë myéloblastique; elle va mourir. Une chaine de 270 dommeurs de sang lui permet de tenir durant la phase d'aplasie avant que la chimiothérapie ne vienne à bout de cette leucémie. 8 ans après, son mari exige que chaque personne qui lui est venue en aide se fasse tester pour le virus de l'hépatite C: car l'une ou l'autre d'entre elles lui a malencontreusement passé ce virus silencieux, inconnu à cette époque, car récemment découvert en 199(). Cette exigence se double, d'une impériosité judiciaire et financière. Il faut indemniser.

Un homme de 57 ans a un anévrisme de l'aorte en 1976, il est opéré car l'anévrisme se fissure. 20 persomnes domnent leur sang. Il est sauvé. 18 ans après, on lui découvre le virus de l'hépatite $C$ dont la contamination a certes pu se faire depuis cette époque par transfusion mais aussi par d'autres voies inconnues non transfusionnelles. Cet homme exige devant le tribunal réparation et demande que l'on recherche les domneurs de sang " coupables".

Une femme est opérée en mars 199() d'une arthrose de la hanche. L'intervention a lieu et nécessite quelques transfusions car elle a été très hémorragique. Quelques semaines après, la femme fait une jaunisse. En 1994, on découvre que celle-ci est liée à une hépatite C: car la sérologie est positive et la "rumeur" l'encourage à déposer plainte contre l'auteur présumé de la contamination. Son avocat demande qu'on poursuive aussi celui qui a simplement tenté de reconstituer l'histoire sans y avoir participé, car cette reconstitution ne se fait peut-être pas avec la célérité voulue par la plaignante.

Ces trois histoires somt vraies. l'absurde le dispute à l'odieux.

"Plainte pour assistance a personne en danger. "Cet égoïsme, cet individualisme forcené, cette immaturité tiennent plus des vautours qui justement flairent le sang et guettent l'argent. Quelle société que celle qui encourage les survivants des catastrophes à déposer plainte contre leurs sauveteurs! Faut-il admettre et cautionner cette incapacité à prendre en charge sa propre vie

\section{Didier Sicard}

Chef de service de Makudies Infectieuses, service de médecine interne, groupe hospilalier Cochin, 27, mu du Faubourg Sainl-Jacques, 75679 Paris Cedex 14, France. 